\title{
Information on the Prevalence and Extent of Alcohol Abuse Among Commercial Tricycle Operators in Calabar
}

\author{
Pius U. Angioha ${ }^{\mathrm{a}}$, Abayomi Akintola ${ }^{\mathrm{a},{ }^{*}}$, Olusola Ogunnubi ${ }^{\mathrm{a}}$, \& Bassey Eyong Butum ${ }^{\mathrm{b}}$ \\ ${ }^{a}$ Department of Sociology, University of Calabar, Nigeria \\ ${ }^{b}$ Department of Political science, Carleton University, Otawa, Canada
}

\begin{abstract}
This study aims to provide information on the prevalence and extent of Alcohol abuse among commercial tricycle operators in Calabar, Cross River State, Nigeria. Adopting a descriptive quantitative research method, data was collected from 385 participants from 6424 registered tricycle operators in Calabar using a questionnaire. The participants were selected using the convenience and random sampling technique. Data collected from the field were subjected to descriptive statistics. Out of the 385 distributed instruments, 383 were returned and used for data analysis. From the analyzed data, the result revealed that all the participants, 100.00 per cent, have taken alcohol before. 81.46 per cent taken alcohol before while working, Majority of the tricycle drivers, 38.90 per cent believes that alcohol makes them have clearer vision when driving, 31.59 per cent argued that it makes them work longer, 10.97 per cent maintain that it is because they are used to alcohol. 12.27 per cent of the participants take alcohol at every opportunity they get, 18.02 per cent reported drinking every day. Result also revealed that all the tricycle riders have had accidents before, 77.81 per cent were under the influence of Alcohol when the accidents happened. Based on this result, the study informs that there was a high prevalence of alcohol abuse among tricycle riders in Calabar. Hence there is a need for the enactment of proper laws that determines the legal limit of alcohol among drivers to checkmate the issue of driving under the influence and its attendant consequences.
\end{abstract}

(C) 2021 Author(s). All rights reserved.

Keywords: Alcohol Abuse, Prevalence, Extent, Commercial Tricycle Operators, Calabar.

\section{Introduction}

Alcohol addiction is a significant global health concern. It is the most costly and common drug addiction problem globally (Molina, Gardner, Souza-Smith \& Whitaker, 2014; Carter, Sharon \& Stern, 2014; WHO, 2018). Alcohol is a psychoactive and toxic substance that contains dependency properties (WHO,2019). In its addictive state, it refers to uncontrollable drinking as a result of the physical and emotional dependence on alcohol beverages (Vengelence, Bilbao, Molander \& Spanagel,2008). According to the study by Rehim, Mathers, Popova, Thayorn charoensap, Teerawaltanaron and Patra (2009). Alcohol is ranked third among the risk factor of disease globally and contributes 7.1 per cent and 2.2 per cent of the world's disease burden for male and female respectively. The Nation Survey on Drug Use and Health (2018) reported that 86.3 per cent of the global population aged between 18 and above reported taking alcoholic substance once in their lifetime, 70 per cent have taken alcoholic substance in at least once in the past year and 65.83 per cent reported taking alcohol in the past month.

The world health organization (2019) reported that alcohol contributes to 3 million death annually, representing 5.3 per cent of all deaths and is a causal factor for more than 200 diseases and injury globally. The report also points to the fact that alcohol addiction results in early disability and death. 13.5 deaths between the ages of 20-39 are attributed to alcohol addiction (World Health Organization,2019) In Nigeria, alcoholic beverages are the most available consumer product and the country ranked $27^{\text {th }}$ globally form alcohol consumption in litres per year for

\footnotetext{
* Corresponding author.

E-mail address: akintola.abayomi.aa@gmail.com (Abayomi Akintola)
} 
people aged 15 and above, making it the leading African nation with alcohol addiction (WHO, 2014). According to Abiona, Oluwasanu, and Oladepo (2019), these figures fails to take into account the unrecorded production and consumption of the locally made illicit alcohol beverages that are found in every corner of the Nigerian society. According to the National Bureau of Statistics (2017). In 2016, 208 billion Nigerian naira was spent on alcohol, with the South-South Region spending the highest on alcohol, spending 74.4 billion naira on alcohol consumption.

In terms of the rural-urban divide, statistics provided by the National Bureau Statistics show that rural communities spend more than 12.5 billion naira on the consumption compared to 82.5 billion naira by urban communities (NBS, 2019). Alcohol has been associated with high morbidity and mortality in some disease and violent injury among which accidents is the highest (Papalimpen, Athanasehs, Mira, Papousis, Spiliopolous \& Papadodima, 2019; Omang, Agba \& Archibong, 2018; Ibiam, Bekomson, \& Angioha, 2019). According to the World Health Organization (2018) alcohol has been attributed to death for both male and female for cirrhosis $(42,120)$ road accidents $(15,365)$ and cancer (4687) in Nigeria. Odueme (2008) also report that drink driving accidents are among the major cause of death in Nigeria and death from accidents accounts for 21.4 per cent per 100,000 death in Nigeria. Although most of the accidents in Nigeria could also be blamed on poor car maintenance culture and the poor road network, driving under the influence of alcohol is a significant factor (Akosu, Afolarammi \& Usar, 2018).

The introduction of tricycle into the Nigeria transport scene has helped in making transportation less stressful and their inherent advantage of providing door to door service, maneuverability of traffic congestion. But recent studies have shown that tricycles are prone to accidents and these accidents have been attributed to the drivers been drunk. The studies of Abiona and Fatoye (2006) have been shown that 59.5 per cent of tricycle accidents have been attributed to alcohol consumption but there has been no study on the alcohol habits of tricycle operators in Calabar. This study attempts to provide information on the prevalence and extent of alcohol abuse among tricycle operators in Calabar.

\section{Materials and Methods}

\subsection{Study Settings}

The study area, Calabar is situated in the Southern Senatorial District of Cross River State, Nigeria between the Great Kwa River and the Calabar River, Calabar covers an area of 223.325 square kilometres and is popularly known with the slogan Canaan City, Calabar is divided into two local government area for administrative purposes; Calabar south and Calabar municipal. According to the National Population Commission (2006), the city has a population of 371,022 and 74,580 households. Originally the home of the Quas, Efut and the Efiks, the city is now home to other ethnic groups from other neighbouring states and Local Government area because of its designation as the administrative capital of Cross River State (Ukwayi, Angioha, \& Aniah, 2019; Angioha, Omang, Ishie, \&Iji, 2020; Angioha, P. U., Nwagboso, Ironbar, \& Ishie, 2018). Also because of the presence of industries and other job opportunities. There has been a geometric rise in the population as a result of migration, the Liyel Imoke government of cross river state had to stop motorcycle as a form of transportation in the state because it's increasing use by miscreant and criminals to commit crime, hence the rise in the use of tricycle for commercial transportation in the area.

\subsection{Study Method}

The descriptive quantitative research method was used for the study. Adopting the descriptive quantitative method, a survey questionnaire was developed by the researchers for the study. A direct field survey was carried out by the researchers and field assistant using the developed instrument. The instrument was a semi-structured survey questionnaire made up of 14 items.

\subsection{Participants Selection}

385 participants were used for the study. According to the information provided by the Calabar Keke Riders Association of Calabar, there are 6,424 registered tricycles operators in Calabar. Using the survey monkey sample size determinant technique, at a confidence level of 95 per cent and a margin of error of 5 per cent, 385 participants were selected. the convenience and random sampling technique were used to select the participants from the study 
area. The convenience sampling was used in selecting 20 areas in Calabar, the areas selected are; Abang Assang, Atimbo, Ujimco, Orok Orok, Mount Zion, Yellow Duke, Ekpo Abasi, Anantigha, Mbukpa, Edgerly, Watts, Chambley, Edibe Edibe, Satelite town, Unical road, Edim Otop, New Airport road, \& Lagos street. These areas were selected because of them being where the tricycle riders have their parks. from these selected areas 20 tricycle riders were randomly selected from 16 of the areas and 21 from 3 . The criteria for selection was that the participants must be a tricycle rider and must have driven for 6 months or more

\subsection{Ethical Consideration}

Ethical clearance was collected from the Keke Riders Association of Calabar for the research to be carried out. Also, both written and verbal approval was obtained from each of the participants for the study. The anonymity of each participant was assured. The researchers and field assistants also explained to the participants the process of the research.

\subsection{Data Collection and Analysis}

The researchers employed the assistance of 4 field assistant who helped in the distribution of the instrument. Data collection covered three weeks and followed due research ethics. Data collected from the field were checked for errors and missing information, they were then arranged and subjected to descriptive statistics, tables, frequency distribution, percentages and charts out of the 385 distributed survey instruments, 383 were returned and used for data analysis.

\section{Result}

\subsection{Presentation of Result}

A Self-developed semi-structured questionnaire was developed for the study. the questions were based on the objectives of the study. descriptive statistics such as frequency distribution and graph were used to analyze the result.

Table 1. Descriptive Analysis or response on Prevalence and Extent of Alcohol Abuse Among Commercial Tricycle Operators in Calabar

\begin{tabular}{|c|c|c|c|c|}
\hline $\mathrm{S} / \mathrm{N}$ & Item & Yes & $\begin{array}{l}\text { I have other } \\
\text { business(s) }\end{array}$ & I do it part-time \\
\hline 1 & $\begin{array}{l}\text { Commercial tricycle is my only } \\
\text { source of income }\end{array}$ & $207(54.05)$ & $113(29.50)$ & $63(16.45)$ \\
\hline
\end{tabular}

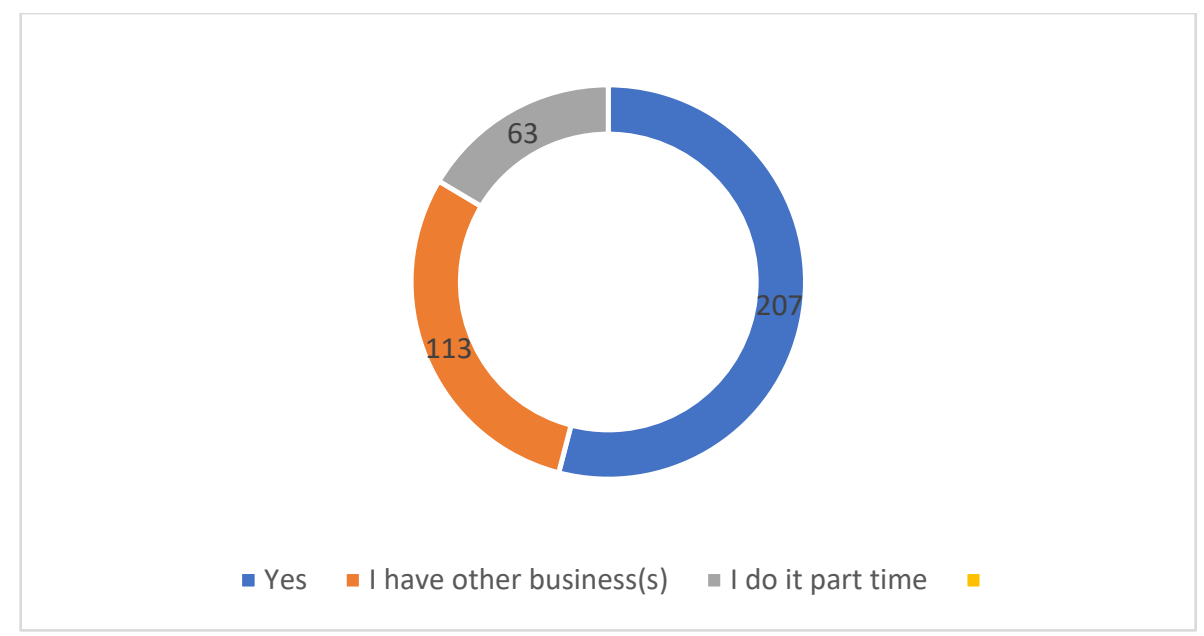

Fig. 1. Responses on Commercial tricycle is my only source of income 
Table 2. Descriptive Analysis or response on Prevalence and Extent of Alcohol Abuse Among Commercial Tricycle Operators in Calabar

\begin{tabular}{|c|c|c|c|c|c|c|c|}
\hline $\mathrm{S} / \mathrm{N}$ & Items & Everyday & Six-time & Five-time & $\begin{array}{c}\text { Three } \\
\text { times a } \\
\text { week }\end{array}$ & $\begin{array}{l}\text { Twice a } \\
\text { week }\end{array}$ & $\begin{array}{c}\text { Any } \\
\text { time I } \\
\text { feel like }\end{array}$ \\
\hline 2 & $\begin{array}{l}\text { How many times in a week } \\
\text { do you ride }\end{array}$ & $109(28.16)$ & $\begin{array}{c}143 \\
(37.33)\end{array}$ & $\begin{array}{c}87 \\
(22.72)\end{array}$ & $31(8.09)$ & $8(2.09)$ & $5(1.31)$ \\
\hline
\end{tabular}

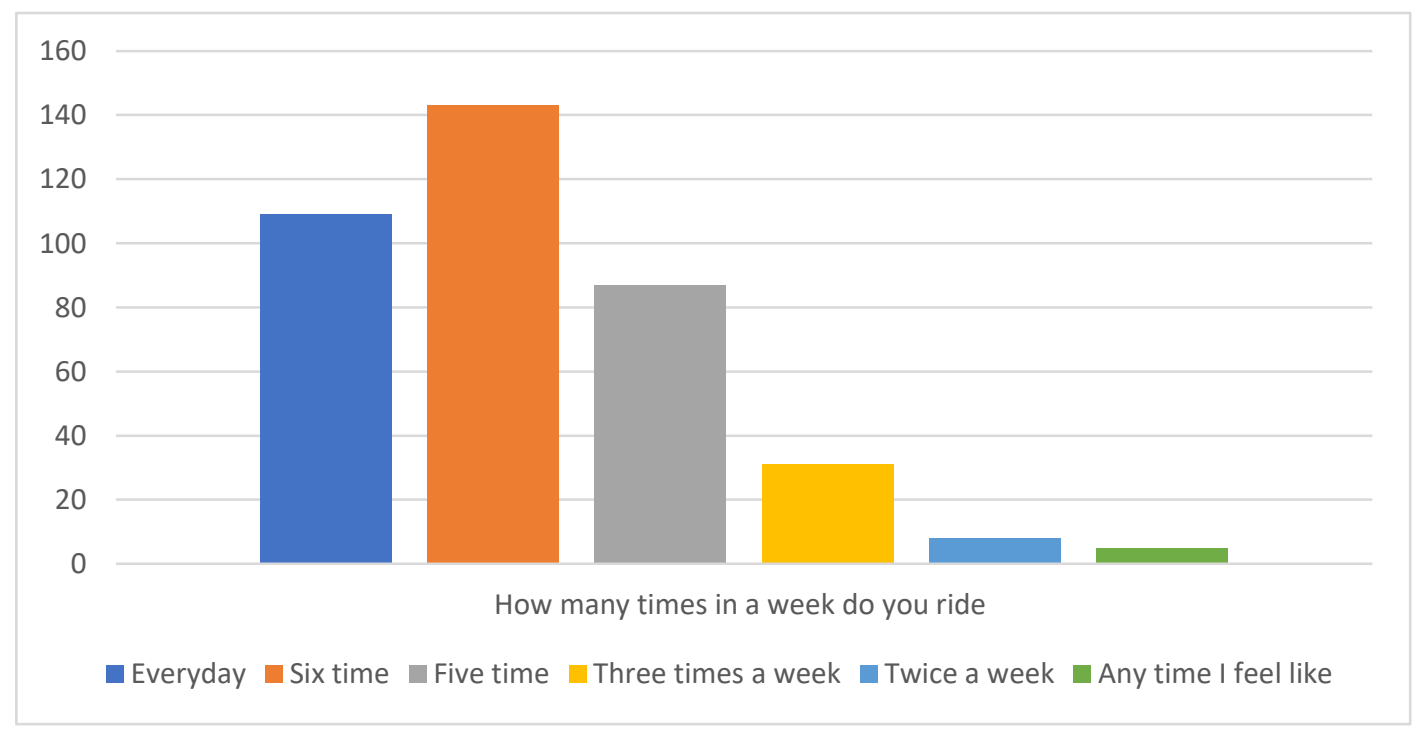

Fig. 2. Responses on How many times in a week do you ride

Table 3. Descriptive Analysis or response on Prevalence and Extent of Alcohol Abuse Among Commercial Tricycle Operators in Calabar

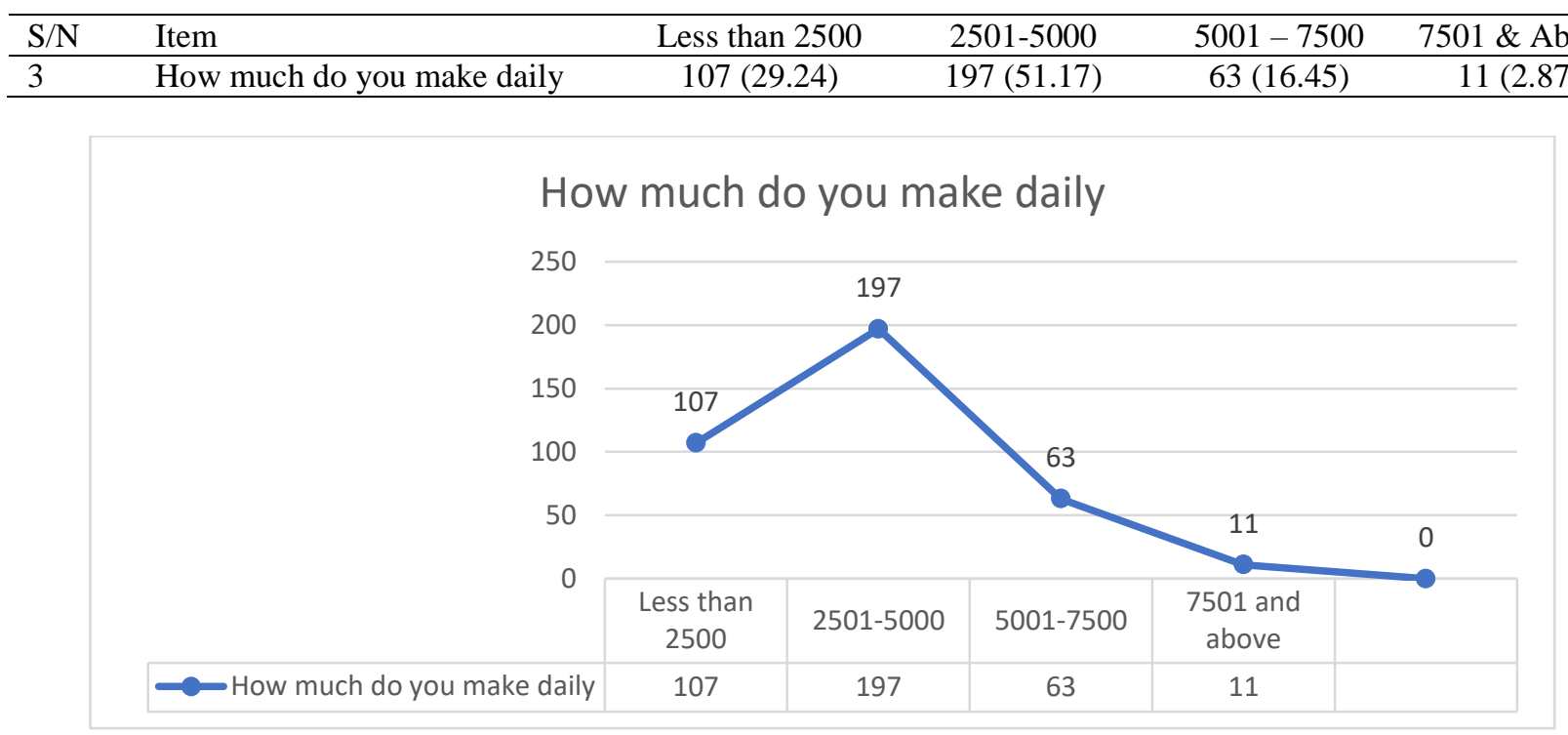

Fig. 3. Responses on daily earnings 
Table 4. Descriptive Analysis or response on Prevalence and Extent of Alcohol Abuse Among Commercial Tricycle Operators in Calabar

\begin{tabular}{llcc}
\hline S/N & Items & Yes & No \\
\hline 4. & I have taken alcohol before & $383(100.00)$ & 0 \\
5. & I have taken alcohol during periods when I am on the road before & $312(81.46)$ & $71(15.54)$ \\
\hline
\end{tabular}

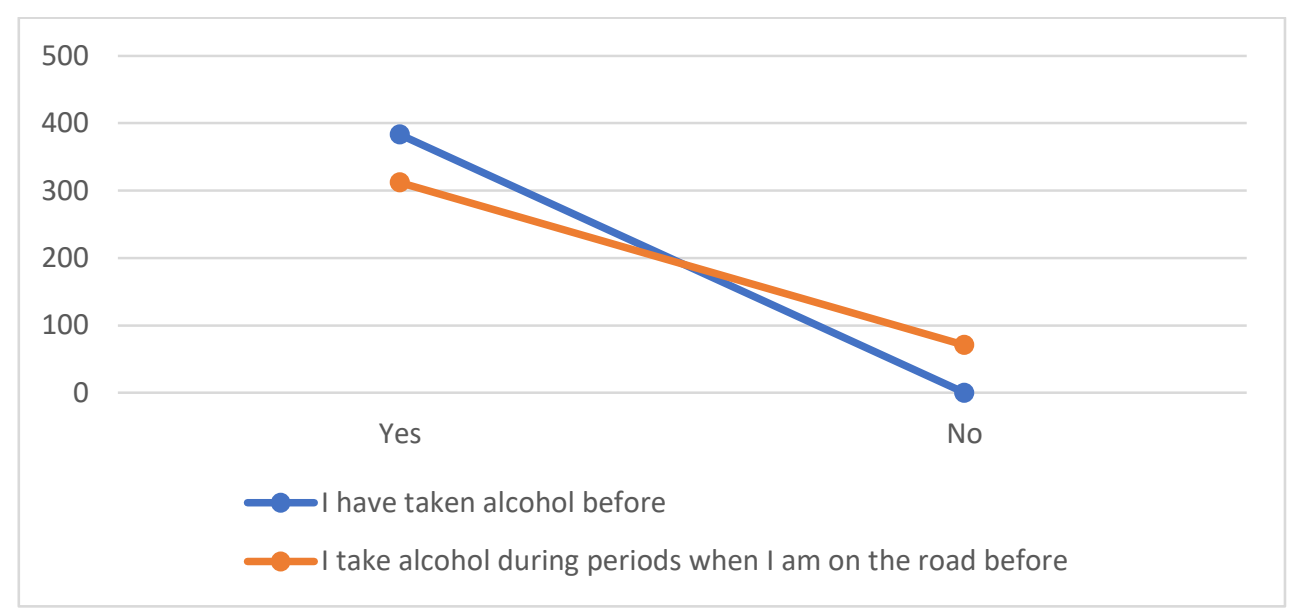

Fig. 4. Responses on taking alcohol before and during the period on the road

Table 5. Descriptive Analysis or response on Prevalence and Extent of Alcohol Abuse Among Commercial Tricycle Operators in Calabar

\begin{tabular}{llcccc}
\hline S/N & Item & $\begin{array}{c}\text { Clearer } \\
\text { vision }\end{array}$ & $\begin{array}{c}\text { Work } \\
\text { longer }\end{array}$ & $\begin{array}{c}\text { I am used to } \\
\text { alcohol }\end{array}$ & $\begin{array}{c}\text { Don’t drink } \\
\text { alcohol }\end{array}$ \\
\hline 6 & $\begin{array}{l}\text { Why did you take alcohol while on } \\
\text { the road }\end{array}$ & $149(38.90)$ & $121(31.59)$ & $42(10.97)$ & $71(15.54)$ \\
\hline
\end{tabular}

\section{Why did you take alcohol while on the road}

\begin{tabular}{|l|l|l|l|l|l|}
\hline Why did you take alcohol while on \\
the road
\end{tabular}

Fig. 5. Responses on Why did you take alcohol while on the road 
Table 6. Descriptive Analysis or response on Prevalence and Extent of Alcohol Abuse Among Commercial Tricycle Operators in Calabar

\begin{tabular}{llccccc}
\hline S/N & Item & $\begin{array}{c}\text { Every opportunity } \\
\text { I get }\end{array}$ & Everyday & $\begin{array}{c}\text { Twice a } \\
\text { week }\end{array}$ & $\begin{array}{c}\text { Occasionally } \\
\text { Don't drink } \\
\text { alcohol }\end{array}$ \\
\hline 7 & How often do you drink & $48(12.27)$ & $69(18.02)$ & $83(21.67)$ & $112(29.24)$ & $71(15.54)$ \\
\hline
\end{tabular}

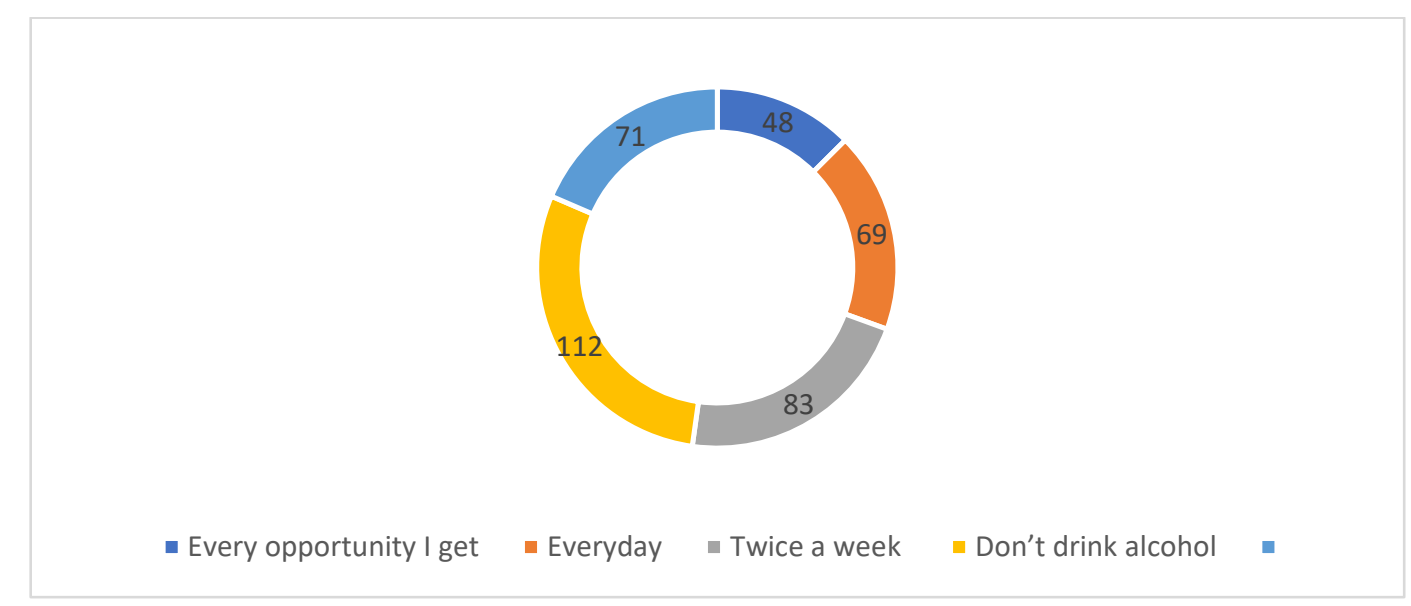

Fig. 6. Responses on How often do you drink

Table 7. Descriptive Analysis or response on Prevalence and Extent of Alcohol Abuse Among Commercial Tricycle Operators in Calabar

\begin{tabular}{lllll}
\hline $\mathrm{S} / \mathrm{N}$ & Item & Yes & No & Not Sure \\
\hline 8 & Have you ever had an accident before & $339(88.51)$ & $44(11.49)$ & 0 \\
\hline
\end{tabular}

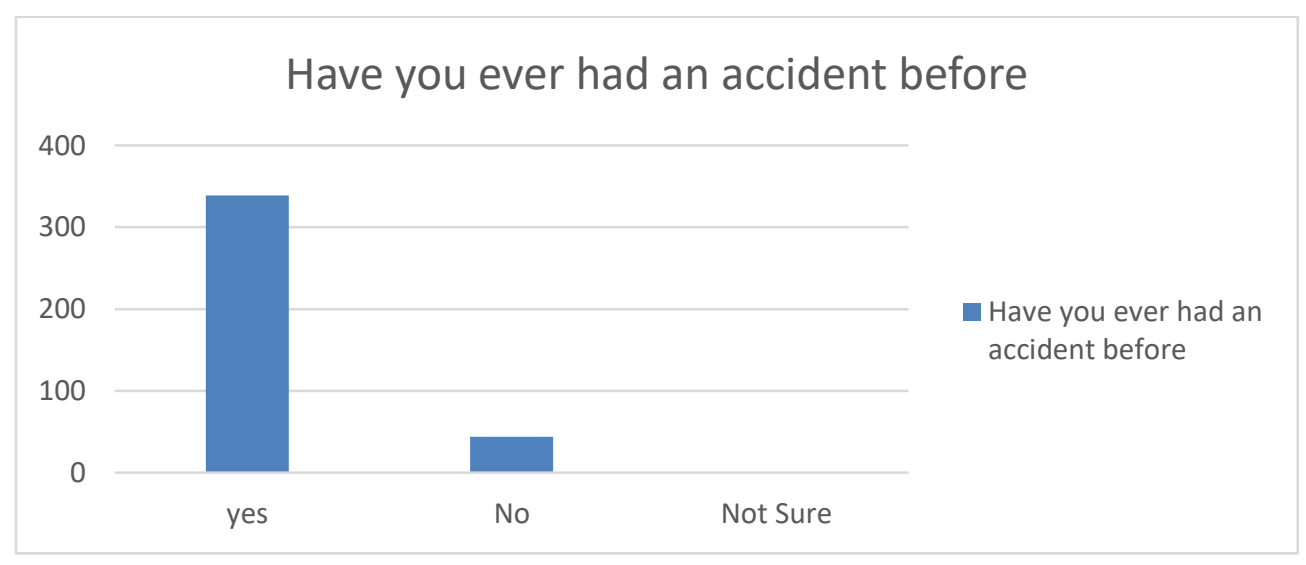

Fig. 7. Graphic illustration of Responses on have you ever had an accident before

Table 8. Descriptive Analysis or response on Prevalence and Extent of Alcohol Abuse Among Commercial Tricycle Operators in Calabar

\begin{tabular}{llccc}
\hline S/N & Item & Yes & No & No Accident \\
\hline 9 & Was the accident serious & $118(34.81)$ & $221(65.19)$ & $44(11.49)$ \\
10 & When the accident occurred, where there & $283(83.48)$ & $57(16.81)$ & $44(11.49)$ \\
& people inside & & & \\
\hline
\end{tabular}




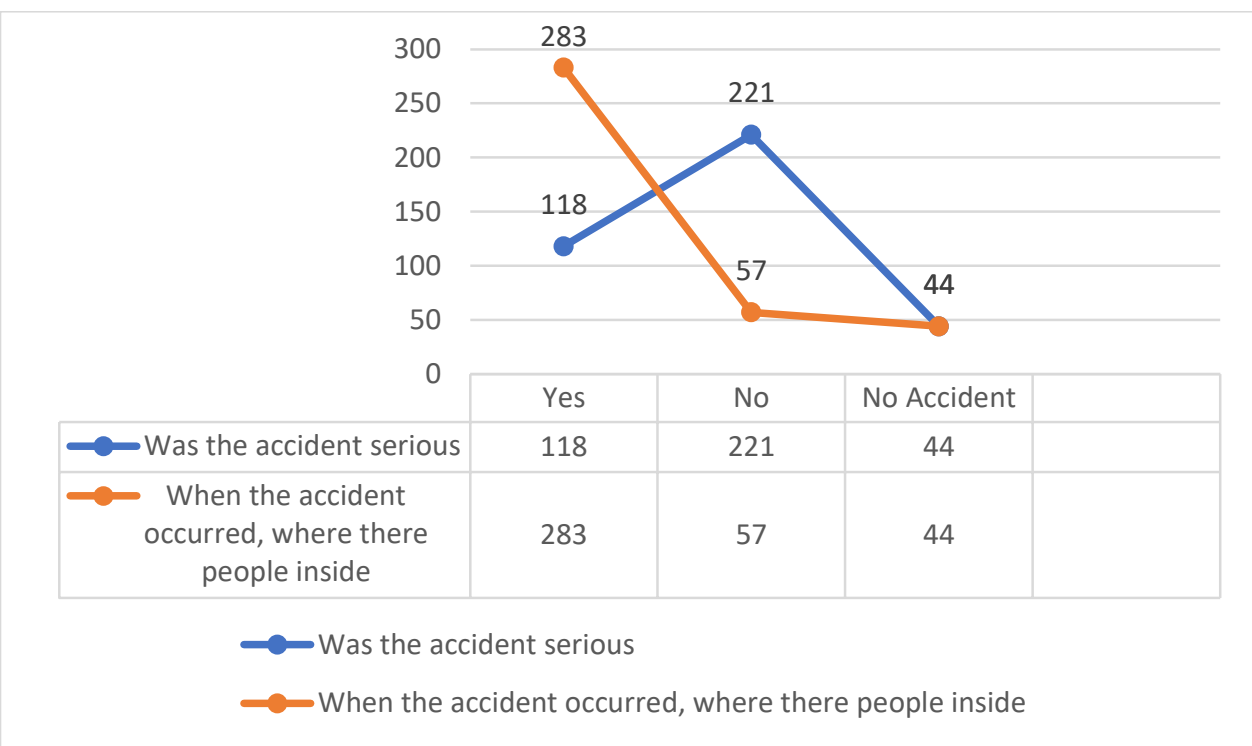

Fig. 8. Responses on prevalence and Extent of Alcohol Abuse Among Commercial Tricycle Operators in Calabar

Table 9. Descriptive Analysis or response on Prevalence and Extent of Alcohol Abuse Among Commercial Tricycle Operators in Calabar

\begin{tabular}{llccc}
\hline S/N & item & Yes & No & Not sure \\
\hline 10 & Did you take any alcohol before the accident & $21(5.48)$ & $302(78.85)$ & $61(15.93)$ \\
11 & $\begin{array}{l}\text { Do you know any of your colleagues who have had an } \\
\text { accident }\end{array}$ & $383(100.00)$ & 0 \\
12 & $\begin{array}{l}\text { When they had the accident, had they taken any } \\
\text { alcohol }\end{array}$ & $298(77.81)$ & $36(9.40)$ & $49(12.79)$ \\
\hline
\end{tabular}

When they had the accident, had they taken any alcohol

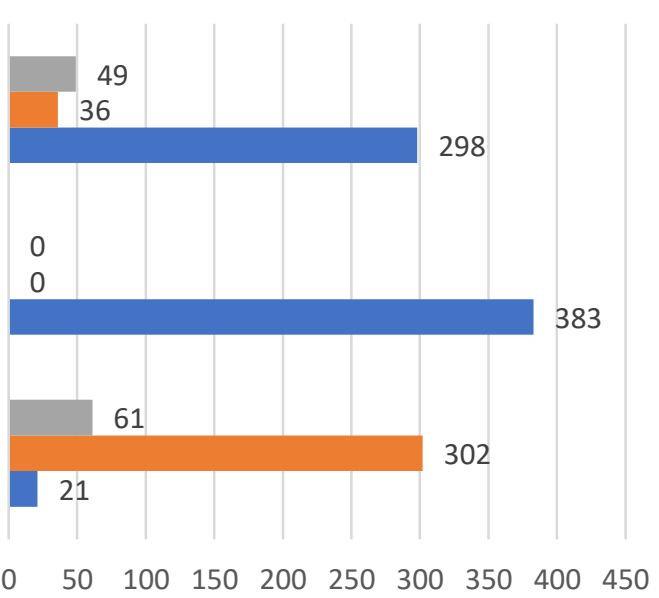

Not Sure $\quad$ No $\quad$ Yes

Fig. 9. Responses on prevalence and Extent of Alcohol Abuse Among Commercial Tricycle Operators in Calabar 
Table 10. Descriptive Analysis or response on Prevalence and Extent of Alcohol Abuse Among Commercial Tricycle Operators in Calabar

\begin{tabular}{llccc}
\hline S/N & Item & Yes & No & Not Sure \\
\hline 13 & The accidents your colleagues had, was it serious? & $275(71.80)$ & $78(20.37)$ & $30(7.83)$ \\
14 & In the accident that your colleagues had been there fatalities & $124(32.38)$ & $196(51.17)$ & $63(16.44)$ \\
\hline
\end{tabular}

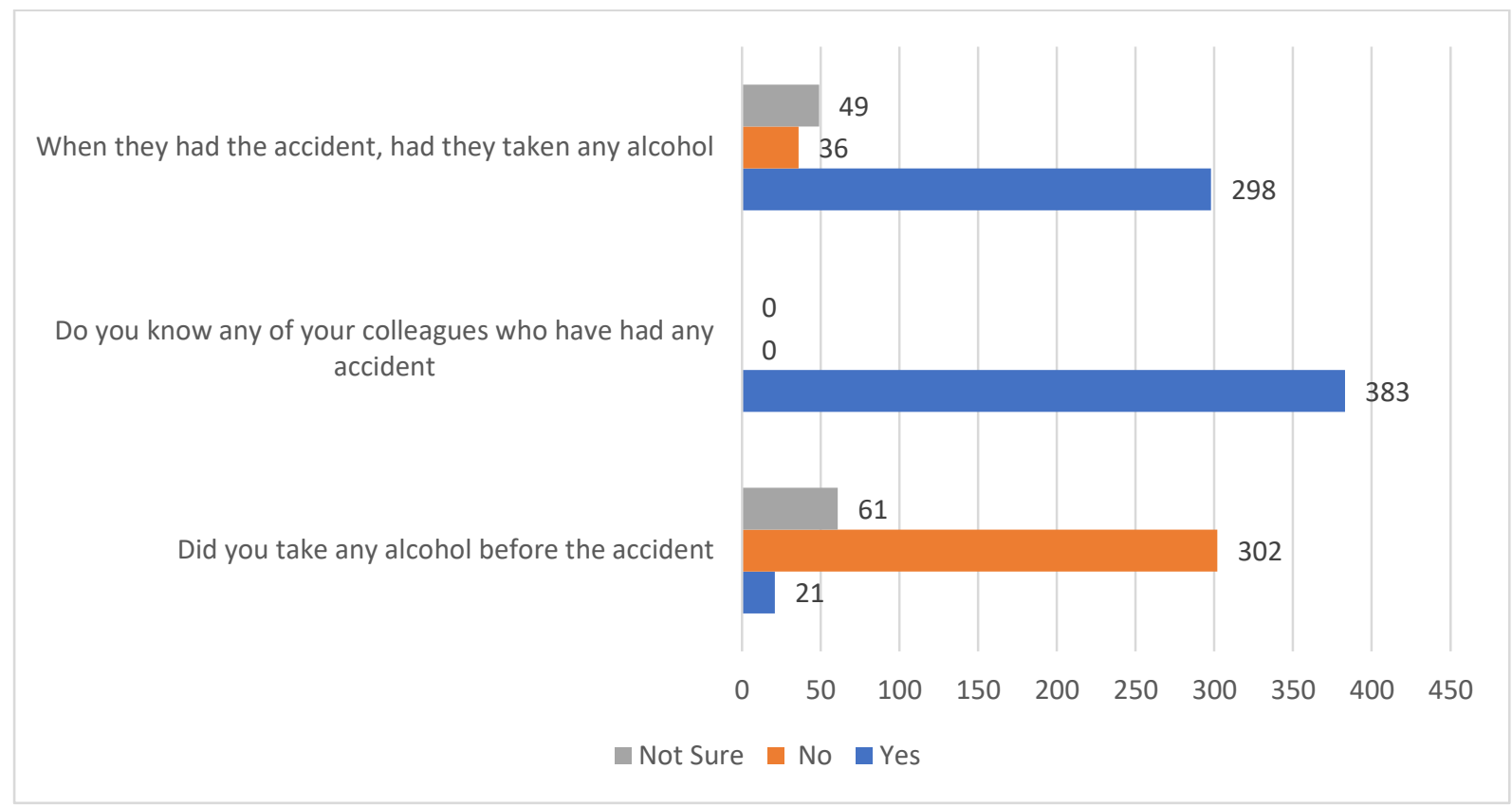

Fig. 10. Responses on prevalence and Extent of Alcohol Abuse Among Commercial Tricycle Operators in Calabar

From the analysis of the data collected from the field by the researchers, it was discovered thus: on commercial tricycle is my only source of income; 207 representing 54.05 per cent of the participants reported "Yes", 113 representing 29.50 per cent reported "I have other business(s)", 63 representing 16.45 per cent reported, "I do it parttime". On How many times in a week do you ride; 109 representing 28.16 per cent of the participants reported "every day", 143 representing 37.33 per cent reported "six Times", 87 representing 22.72 reported "Five times", 31 representing 8.09 per cent reported "Three times", 8 representing 2.09 per cent reported "Twice a week" and only 5 representing 1.31 per cent reported, "Any time I feel like". On how much do you make daily; 107 representing 29.24 per cent reported "Less than 2500 naira", 197 representing 51.17 per cent reported "2501 to 5000 naira". On I have taken alcohol before; 383 representing 100. 00 per cent of the participants reported "Yes", while none of the participants reported "No". On I have taken alcohol during periods when I am on the road before; 312 representing 81.46 per cent of the participants reported "Yes", while 71 representing 15.54 per cent reported "No". On why did you take alcohol while on the road; 149 representing 38.90 per cent of the participants reported "for clearer Vision", 121 representing 31.59 per cent reported "to Work longer", 42 representing 10.97 per cent of the participants reported "I am used to alcohol" and 71 representing 15.54 per cent of the participants reported, "Don't drink alcohol".

On how often do you drink; 48 participants representing 12.27 per cent reported "every opportunity I get", 69 participants representing 18.02 per cent reported "every day", 83 participants representing 21.67 per cent reported "Twice a week", 112 participants representing 29.24 per cent reported "Occasionally" and 71 participants representing 15.54 per cent reported, "Don't drink alcohol". On have you ever had an accident before; 339 participants representing 88.51 per cent reported "Yes", 44 participants representing 11.49 per cent reported "No", while non reported, "Not sure". On was the accident serious; 118 participants representing 34.81 per cent Reported "Yes", and 221 participants representing 65.19 per cent reported "No". On when the accident occurred, where their 
people inside; 283 participants representing 83.48 per cent reported "Yes", while 57 participants representing 16.81 per cent reported "No". On did you take any alcohol before the accident; 21 participants representing 5.48 per cent reported "Yes", 302 participants representing 78.85 per cent reported "No" and 61 participants representing 16.93 per cent reported, "Not Sure". On do you know any of your colleagues who have had any accident; 383 participants representing 100.00 per cent reported "Yes", while non reported "No". On when they had the accident, had they taken any alcohol; 298 participants representing 77.81 per cent reported "Yes", 36 participants representing 9.40 per cent reported "No" and 49 participants representing 12.79 per cent reported, "Not sure". On The accidents your colleagues had, was it serious? 275 participants representing 71.80 per cent reported "Yes", 78 participants representing 20.37 per cent reported "No" and 30 participants representing 7.83 per cent reported, "Not Sure". On in the accident that your colleagues had were there fatalities; 124 participants representing 32.38 per cent reported" Yes", 196 participants representing 51.17 per cent reported "No" and 63 participants representing 16.44 per cent reported, "Not sure".

\subsection{Discussion of Results}

From the analysis of the data collected from the field and subjected to descriptive statistics such as frequency distribution, simple percentages and charts. Result revealed that majority of tricycle riders 81.46 per cent, take alcohol, when on the road. This is a common trend in most states and cities in Nigeria, you can hardly find a driver who drives commercial transport especially in rural communities, who do not take alcohol when on the road. This is easier because car parks and garages are hotspots for dealers of all kinds of alcoholic beverages. This finding is supported by that of Abiona, Aloba and Fatoye (2006), whose study finding on pattern of Alcohol consumption among road transport workers in South Western Nigeria revealed that 67 per cent of the participants (drivers) use alcohol when on the road. Bello, Ndifon, Mpama and Oduwole (2011) in their study on the pattern of alcohol addiction among commercial drivers in Calabar found that 84.4 per cent of commercial drivers use alcohol during workdays.

The result from the analysis also revealed that the reason for taking alcohol was that it gives them a clearer vision (38.90 per cent), it makes them work longer (31.59 per cent). The reason for this could be attributed to the aphrodisiac nature of some of the alcoholic beverage that most of these drivers take, especially the local illicit gin. These alcoholic beverages are readily available at motor parks, Garages, where this tricycle riders pick their passengers and park their tricycles. Most often this local illicit gin is mixed with other hard substance that abusers feel give them extra motivation. Result also revealed that 1227 per cent of the respondents take alcohol at every opportunity they get, while 18.67 per cent take it every day.

Also, most of the participants agreed that they have been in one accident or the other and 83.48 per cent of the respondents had people inside the tricycle when they had the accidents. But most of the participant, 78.85 per cent maintain that when they had the accident, they were not under the influence of alcohol. But when asked about their colleagues that had accident 77.81 per cent believed that they believed that those colleagues were under the influence of alcohol. This finding supports the works of Papalimperi, Athanaselis, Mina, Papoutsis, Spiliopoulou, and Papadodima (2019), who found that 40 per cent of road traffic accidents are as a result of alcohol consumption. The study of Oridota, Ashindoitiang, Olatona, Olajide, Akanmu, and Soriyan (2003) study found that 44.9 per cent of commercial drivers have accidents because of alcohol and substance utilization.

\section{Conclusion and Policy Implication}

This study aimed to provide information on the prevalence and extent of Alcohol abuse among commercial tricycle operators in Calabar. From the analyzed data using descriptive statistics, it was discovered that there was a high prevalence of alcohol abuse among tricycle riders in Calabar. Hence there is a need for the enactment of proper laws that determines the legal limit of alcohol among drivers to checkmate the issue of driving under the influence and its attendant consequences. Also, the use of breathalyzers should be introduced for use by traffic enforcement agencies and security officers to check the amount of alcohol in the system of commercial drivers. 


\section{References}

Abiona, O., Oluwasanu, M. \& Oladepo, O. Analysis of alcohol policy in Nigeria: multi-sectoral action and the integration of the WHO "best-buy" interventions. BMC Public Health 19,810 (2019). https://doi.org/10.1186/s12889-019-7139-9

Abiona, T. C., Aloba, O. O. \& Fatoye, F. O. (2006). Pattern of alcohol consumption among commercial road transport workers in a semi-urban community in South-West Nigeria. East Afr Med J, 83:494-9.

Angioha, P. U., Nwagboso, S. N., Ironbar, A. E. \& Ishie, E. U. (2018). Underemployment: A Sociological and Policy Analysis of Workers Well-Being in Hospitality Industry in Calabar, Cross River State, Nigeria. IOSR Journal of Humanities and Social Science (IOSR-JHSS), Volume 23, Issue 6, Ver. 5 (June. 2018) PP 57-66.

Angioha, P. U., Omang, T. A., Ishie, E. U. \&Iji, M. E. (2020). "Employee Stressors and Wellbeing of Healthcare Workers in Government owned Hospitals in Calabar, Nigeria", Journal of Public Administration, 2(4), 2020, pp. 36-43.

Bello, S., Ndifon, W. O., Mpama, E. A. \& Oduwole, O. O. (2011). Pattern of alcohol use among drivers of commercial vehicles in Calabar, Nigeria. East African Medical Journal. 88(3):75-79

Carter, J., Sharon, E., \& Stern, T. A. (2014). The management of alcohol use disorders: the impact of pharmacologic, affective, behavioural, and cognitive approaches. The primary care companion for CNS disorders, 16(4), 10.4088/PCC.14f01683. https://doi.org/10.4088/PCC.14f01683

Francis, J. M., Weiss, H. A., Mshana, G., Baisley, K., Grosskurth, H. \& Kapiga, S.H. (2015). The Epidemiology of Alcohol Use and Alcohol Use Disorders among Young People in Northern Tanzania. PLoS One. 2015;10(10):e0140041. Published 2015 Oct 7. doi:10.1371/journal.pone.0140041

Ibiam, A. A., Bekomson, E. M., \& Angioha, P. U. (2019). Socio-Environmental Factors as Determinants of Social Wellbeing of Adolescents In Calabar, Cross River State, Nigeria. European Journal of Public Health Studies, 1(2), 164-175. https://doi.org/10.5281/zenodo.3597522

Molina, P. E., Gardner, J. D., Souza-Smith, F. M., \& Whitaker, A. M. (2014). Alcohol abuse: critical pathophysiological processes and contribution to disease burden. Physiology (Bethesda, Md.), 29(3), 203215. https://doi.org/10.1152/physiol.00055.2013

Omang, T. A., Agba A. M. O. \&Archibong, S. J. (2018). Lifestyle and Employees' Health-A Critical Review. International Journal of Public Administration and Management Research (IJPAMR). 4(4):82-88.

Oridota, S. E., Ashindoitiang, M. A. U., Olatona, F. A., Olajide, T. O., Akanmu, O. N. \& Soriyan, O. O. (2003). Substance and alcohol utilization among commercial drivers and its interrelationship with road traffic accident. J Med Res Pract;2(2):65-68

Papalimperi, A.H., Athanaselis, S.A., Mina, A.D., Papoutsis, I.I., Spiliopoulou, C.A., \& Papadodima, S.A. (2019). Incidence of fatalities of road traffic accidents associated with alcohol consumption and the use of psychoactive drugs: A 7-year survey (2011-2017). Experimental and Therapeutic Medicine, 18, 2299-2306. https://doi.org/10.3892/etm.2019.7787

Rehm, J., Mathers, C., Popova, S., Thavorncharoensap, M., Teerawattananon, Y. \& Patra, J. (2009). Global burden of disease and injury and economic cost attributable to alcohol use and alcohol-use disorders. Lancet. 2009;373(9682):2223-2233. doi:10.1016/S0140-676(09)60746-7

Ukwayi, J. K., Angioha, P. U. \& Aniah, E. A. (2019). Associate Factor of Trafficking in Women and Children in Calabar, Cross River State, Nigeria. European Journal of Political Science Studies 3 (1), 1-15

WHO (2020). Alcohol. https://www.who.int/health-topics/alcohol\#tab=tab_1 
Angioha, et.al | JINAV: Journal of Information and Visualization, 2021, 2(1): 50-60

Wole, M. (2012). An analysis of motorcycle traffic and crashes in Nigeria - a case study of Minna,Nigeria. Journal of Technological Research. ; 7:59-66.

World Health Organization. (2014). Global status report on alcohol and health, 2014. Geneva: World Health Organization WHO Press; 2014. 